\title{
Environmental stratification and performance of Coffea canephora clones grown in the Western Amazon
}

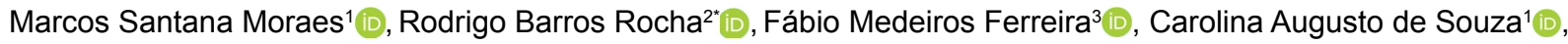 \\ Marcelo Curitiba Espindula² (D), Alexsandro Lara Teixeira² ${ }^{\text {ID }}$
}

\begin{abstract}
${ }^{1}$ Rede de Biodiversidade e Biotecnologia da Amazônia Legal, Programa de Pós-graduação em Biodiversidade e Biotecnologia, Porto Velho, RO, Brasil ${ }^{2}$ Empresa Brasileira de Pesquisa Agropecuária/Embrapa, Centro de Pesquisa Agroflorestal de Rondônia, Porto Velho, Rondônia, Brasil ${ }^{3}$ Universidade Federal do Amazonas/UFAM, Instituto de Ciências Exatas e Tecnologia, Itacoatiara, AM, Brasil

Contact authors: marcosopo16@hotmail.com; rodrigo.rocha@embrapa.br; ferreirafmt@ufam.edu.br; carolinaaugusto22@gmail.com; marcelo.espindula@embrapa.br; alexsandro. teixeira@embrapa.br

Received in April 7, 2021 and approved in September 20, 2021
\end{abstract}

\section{ABSTRACT}

Change in the performance of clones grown in different environments is an important question for Coffea canephora breeding. The aim of this study was to evaluate environmental stratification and the performance of $C$. canephora clones grown in the Western Amazon. For that purpose, the mean yield of three crop seasons was considered to evaluate the performance of 20 genotypes grown in 6 clonal competition trials in the environments of: E1: Ouro Preto do Oeste-RO, E2: Porto Velho-RO, E3: Ariquemes-RO, E4 and E5: Rio Branco-AC and E6: Alta Floresta do Oeste-RO. The trials were conducted with a plant spacing of $3 \mathrm{~m} \times 1.5 \mathrm{~m}$ in a complete block experimental design, with three replications of eight plants per plot. Combined analysis indicated significance of the genotype $\times$ environment $(G \times E)$ interaction and favorable conditions to obtain gains from selection. Reduction in the dimensionality estimated from climate and soil characteristics indicated that the environments of Porto Velho-RO, Rio Branco-AC and Ariquemes-RO are more similar to each other than the environments of Ouro Preto do Oeste-RO and Alta Floresta-RO of greater natural soil fertility and higher altitude. The AMMI1 biplot shows that genotypes 16,10, and 13 had the highest mean yields, together with greater stability. In the AMMI2 scatterplot (IPCA1×IPCA2), the environments E4 and E5 were clustered in the same sector. Clustering based on the complex fraction of the GXE interaction coincided with the AMMI2 scatterplot that clustered the E4 and E5 environments in a single mega-environment. Except for these environments, all the others clustered as locations of different biotic and abiotic stress conditions. This result shows the importance of maintaining evaluations in these environments, which represent the conditions of the coffee fields in the region.

Key words: AMMI; Genotype × environment; Plant breeding.

\section{INTRODUCTION}

The genotype by environment $(\mathrm{G} \times \mathrm{E})$ interaction has numerous implications for breeding of perennial species such as the C. canephora coffee plant (Ferrão et al., 2008; Moraes et al., 2020; Cilas et al., 2011). Change in performance of genotypes grown in different environments is important in clonal selection, which should be conducted in environments with different climatic, edaphic, and crop management conditions, aiming to identify genotypes with wide or specific adaptabilities (Cruz et al., 2014; Gauch et al., 2008, Mistro et al., 2003).

Several breeding methods consider a reduction in the original population, with selection of superior plants and an increase in the number of growing environments (Ferrão et al., 2017; Rocha et al., 2015). Performing clonal tests in different environments is one of the most important and also most costly steps of coffee breeding programs because it considers setting up, maintaining, and evaluating experiments in different locations for several years.

The Western Amazon is composed of the states of Amazonas, Acre, Rondônia, and Roraima, which represents nearly $40 \%$ of the territory of the Brazilian Amazon (Dalazen et al., 2019). In this region, coffee is grown mainly in the state of Rondônia, which produces more than $90 \%$ of all the coffee marketed, a quantity of approximately two million sixtykilogram bags in 2020 (Companhia Nacional de Abastecimento - CONAB, 2020).

Rondônia has a predominantly warm-humid equatorial climate, with three dry months (July, August, September), with greater rainfall and a less accentuated dry season in northern regions of the state (Alvares et al., 2013). In these environments, coffee is grown on different types of soil, with predominance of Oxisols (58\%) and Argisols (11\%) of low natural fertility (Schlindwein et al., 2012).

Due to this diversity among the Western Amazon environments, the occurrence of the genotype by environment interactions of simple and complex types are expected. The latter being characterized by differences in genotype performances when the plants are grown in different locations (Spinelli et al., 2018; Teixeira et al., 2020).

Together with performance analysis of genotypes, procedures of environmental stratification make it possible to determine if the information evaluated in different locations is complementary or redundant (Resende et al., 2007; Carias et al., 2016; Ramalho et al., 2016). Analyses of environmental stratification also allow identifying environments where the 
$\mathrm{G} \times \mathrm{E}$ interaction is of a simple nature or is not significant to inform decisions on future evaluations (Gauch et al., 2008; Cruz et al., 2014).

In this context, the aim of this study was to evaluate the environmental stratification and the performance of $C$. canephora clones grown in the Western Amazon.

\section{MATERIALS AND METHODS}

\subsection{Field trials}

To quantify the performance of the clones in different environments, six clonal tests were performed from 2012 to 2018. The tests were set up in the range of $8^{\circ}$ to $11^{\circ}$ latitude, which corresponds to approximately $260 \mathrm{~km}$ in the northsouth direction, and $62^{\circ}$ to $67^{\circ}$ longitude, which corresponds to approximately $620 \mathrm{~km}$ in the east-west direction.

The environment of Porto Velho, RO, more toward the north, and of Rio Branco-AC, more to the west, is characterized by high rainfall and by Oxisols of low natural fertility (Schlindwein, et al., 2012). The environments of Ouro Preto do Oeste-RO and of Ariquemes-RO are characterized by the low fertility of their Oxisols and by the well-defined dry season in the period from July to September. The municipality of Alta Floresta do Oeste-RO, in turn, is characterized by higher altitude, lower temperature, and soils of greater natural fertility (Alvares et al., 2013).

The genotypes evaluated in the clonal tests comprised of eight open pollinated and twelve full-sib clones (Table 1). The full-sib clones were derived from the directed pollination between genitors from the Conilon and the Robusta botanical varieties (Souza et al., 2013). Four clones of the cultivar Conilon cv. BRS Ouro Preto were also used as controls (Table 1).

In December 2012 and January 2013, six final clonal competition trials were set up in different environments of the Western Amazon, described below:

Clonal competition test $n^{\circ}$. 1: The trial in Ouro Preto do Oeste, RO (E1) was conducted in the experimental field of the Empresa Brasileira de Pesquisa Agropecuária (Embrapa) at $10^{\circ} 43^{\prime} 55.3^{\prime \prime} \mathrm{S}$ and $62^{\circ} 15^{\prime} 23.2^{\prime} \mathrm{W}$, at 245 meters above sea level. The climate of the municipality is type "Aw" by the Köppen classification, defined as tropical humid with a dry winter and rainy summer. Mean annual temperature ranges from $21.2^{\circ} \mathrm{C}$ to $30.3{ }^{\circ} \mathrm{C}$, and the highest temperatures occur in July and August. Mean annual rainfall is $1939 \mathrm{~mm}$ and mean relative humidity is $81 \%$ (Alvares et al., 2013).

Table 1: List of the clones evaluated in six clonal competition trials conducted in five environments of the Western Amazon.

\begin{tabular}{|c|c|c|c|}
\hline $\mathbf{n}$ & Genotype & Origin & Genealogy \\
\hline 1 & BRS Ouro Preto-125 & BRS Ouro Preto Cultivar & Open pollination \\
\hline 2 & BRS Ouro Preto-160 & BRS Ouro Preto Cultivar & Open pollination \\
\hline 3 & BRS Ouro Preto-120 & BRS Ouro Preto Cultivar & Open pollination \\
\hline 4 & BRS2299 & Robustas Amazônicos Cultivar & Open pollination \\
\hline 5 & Clone 453 & 2001 Introduction & Open pollination \\
\hline 6 & Clone 657 & 2001 Introduction & Open pollination \\
\hline 7 & Clone 636 & 2001 Introduction & Open pollination \\
\hline 8 & BRS3193 & Robustas Amazônicos Cultivar & Open pollination \\
\hline 9 & Hybrid 9 & Progeny test & EMCAPA03 x IAC640 \\
\hline 10 & BRS3210 & Robustas Amazônicos Cultivar & EMCAPA03 x IAC2258 \\
\hline 11 & Hybrid 11 & Progeny test & EMCAPA03 x IAC194 \\
\hline 12 & Hybrid 12 & Progeny test & EMCAPA03 x IAC2258 \\
\hline 13 & BRS3213 & Robustas Amazônicos Cultivar & EMCAPA03 x IAC2258 \\
\hline 14 & BRS2314 & Robustas Amazônicos Cultivar & EMCAPA03 x IAC640 \\
\hline 15 & Hybrid 15 & Progeny test & EMCAPA03 x IAC2258 \\
\hline 16 & BRS1216 & Robustas Amazônicos Cultivar & EMCAPA03 x IAC1675 \\
\hline 17 & Hybrid 17 & Progeny test & EMCAPA03 x IAC1675 \\
\hline 18 & Hybrid 18 & Progeny test & IAC640 x CPAFRO194 \\
\hline 19 & Hybrid 19 & Progeny test & IAC1675 x CPAFRO194 \\
\hline 20 & BRS3220 & Robustas Amazônicos Cultivar & EMCAPA03 x IAC1675 \\
\hline
\end{tabular}

Genotypes preceded by the BRS prefix were registered in MAPA/RNC (2020) (Teixeira et al., 2020); IAC: Instituto Agronômico de Campinas; EMCAPA: Empresa Capixaba de Pesquisa Agrícola; CPAFRO: Centro Agroflorestal de Rondônia. 
Clonal competition test $n^{\circ} .2$ : The trial in Porto Velho, RO (E2) was set up in the experimental field of Embrapa at $8^{\circ} 48^{\prime} 05.5^{\prime \prime} \mathrm{S}$ and $63^{\circ} 51^{\prime} 02.7^{\prime \prime} \mathrm{W}$, at 88 meters above sea level. The predominant climate in the region is tropical rainy with a dry winter, type "Am" (Köppen), with mean temperature of $26.0^{\circ} \mathrm{C}$ and mean annual rainfall of $2095 \mathrm{~mm}$. September is the hottest month of the year $\left(27.1^{\circ} \mathrm{C}\right)$, and May is the coldest month $\left(24.9^{\circ} \mathrm{C}\right)$ (Alvares et al., 2013).

Clonal competition test $\mathrm{n}^{\circ}$. 3: The trial in Ariquemes, RO (E3) was set up in the Federal Institute of Rondônia at 0957'09.8' $\mathrm{S}$ and $62^{\circ} 56^{\prime} 53.7^{\prime \prime} \mathrm{W}$, and 128 meters above sea level. The predominant climate in the region is tropical rainy with a dry winter, type "Am" (Köppen), with mean temperature of $26.0^{\circ} \mathrm{C}$ and mean annual rainfall of $2095 \mathrm{~mm}$. Mean annual rainfall is $2181 \mathrm{~mm}$ and mean annual temperature is $25.4{ }^{\circ} \mathrm{C}$; September is the warmest month and July is the driest (Alvares et al., 2013).

Clonal competition tests $n^{\circ} .4$ and $n^{\circ}$. 5: The trials in Rio Branco, AC (E4 and E5) were set up at Embrapa Acre. Geographic coordinates are $10^{\circ} 1$ ' $30.98^{\prime \prime} \mathrm{S}$ and $67^{\circ} 42^{\prime} 21.77^{\prime \prime}$ $\mathrm{W}$ at 180 meters above sea level. The predominant climate is tropical humid, type "Aw" (Köppen), with a well-defined dry season from June to August. Water deficit ranges from 50 to $100 \mathrm{~mm}$ year ${ }^{1}$. Mean annual rainfall is $1998 \mathrm{~mm}$. Mean annual temperature is near $24.9^{\circ} \mathrm{C}$, with October as the hottest month and July as the driest month (Alvares et al., 2013).

Clonal competition test $\mathrm{n}^{\circ}$. 6: The trial at the Alta Floresta do Oeste, RO (E6) environment was conducted on a private property at $12^{\circ} 08^{\prime} 23.06^{\prime \prime} \mathrm{S}$ and $61^{\circ} 59^{\prime} 29.41^{\prime \prime} \mathrm{W}$ at 436 meters above sea level. The climate classification is tropical humid "Aw" (Köppen). Mean annual temperature is near $23.4^{\circ} \mathrm{C}$. Mean annual rainfall is $1783 \mathrm{~mm}$ (Alvares et al., 2013). The soil chemical properties were evaluated in the Soil Analysis Laboratory of Embrapa Rondônia (Table 2).
The clonal competition trials were conducted in randomized block designs with three replicates of eight plants per plot; plots had dimensions of $3 \mathrm{~m} \times 1.5 \mathrm{~m}$. The randomization restriction was performed in the field to maximize homogeneity within each block. Soil nutritional, crop management, and phytosanitary practices at each trial site were carried out according to the recommendations of the Coffee Growing Production System in Rondônia (Marcolan et al., 2009). Four trials evaluated in Ouro Preto do Oeste, Porto Velho, Rio Branco and Alta Floresta do Oeste received complementary irrigation according to the needs of each environment from the first flowering period up to the beginning of the rainy period, which is from July to October. Two trials evaluated in the environments of Ariquemes and Rio Branco were set up and conducted under dryland conditions.

Hulled coffee yield (bag ha-1) was evaluated in the 2014/15, 2015/16, and 2016/17 crop seasons. Each plot was harvested and weighed in the field using a precision balance. After that, $3 \mathrm{~kg}$ samples were collected and then dried on a cement drying yard with a barge-type covering until reaching $11-12 \%$ moisture, thus obtaining the quotient between field coffee and hulled coffee yield. The hulled coffee yield in $60 \mathrm{~kg}$ bags per hectare was determined using the following equation:

Yield $=\frac{\left(\frac{u c}{n p}\right)}{60} *$ nplants $*$ prop

where is coffee yield in bags per hectare; is uncleaned coffee production per plot $(\mathrm{kg})$; is the number of plants per plot; is the number of plants per hectare; is the proportion between hulled coffee and uncleaned coffee expressed in percentage; and 60 corresponds to the weight of a bag of hulled coffee in kilograms.

Table 2: Chemical properties at the 0,0-0,2 and 0,2-0,4 m depth layers of six clonal competition trials (E1 to E6) evaluated in five environments of the Western Amazon.

\begin{tabular}{|c|c|c|c|c|c|c|c|c|c|c|}
\hline \multirow{2}{*}{ Environments } & \multirow{2}{*}{$(\mathrm{m})$} & \multirow{2}{*}{$\mathrm{pH}$} & \multirow{2}{*}{$\mathrm{g} \mathrm{dm}^{-3}$} & K & $\mathrm{Ca}$ & $\mathrm{Mg}$ & $\mathrm{Al}+\mathrm{H}$ & $\mathrm{Al}$ & \multirow{2}{*}{$\frac{\mathrm{OM}}{\mathrm{kg} \mathrm{kg}^{-1}}$} & \multirow{2}{*}{$\begin{array}{l}\mathrm{V} \\
\%\end{array}$} \\
\hline & & & & \multicolumn{5}{|c|}{ 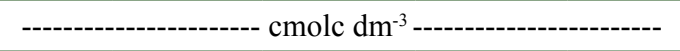 } & & \\
\hline \multirow{2}{*}{$\begin{array}{l}\text { E1 - Ouro Preto } \\
\text { do Oeste }\end{array}$} & $0.0-0.2$ & 5.2 & 0.015 & 0.23 & 2.42 & 0.66 & 4.95 & 0.10 & 0.02 & 40 \\
\hline & $0.2-0.4$ & 5.4 & 0.008 & 0.32 & 2.71 & 0.88 & 5.94 & 0.00 & 0.02 & 40 \\
\hline \multirow{2}{*}{ E2 - Porto Velho } & $0.0-0.2$ & 5.4 & 0.002 & 0.09 & 1.48 & 1.02 & 13.53 & 0.87 & 0.05 & 16 \\
\hline & $0.2-0.4$ & 4.9 & 0.002 & 0.05 & 0.39 & 0.37 & 13.37 & 1.65 & 0.04 & 6 \\
\hline \multirow{2}{*}{ E3 - Ariquemes } & $0.0-0.2$ & 4.4 & 0.001 & 0.04 & 0.29 & 0.10 & 6.27 & 1.26 & 0.02 & 6 \\
\hline & $0.2-0.4$ & 4.4 & 0.001 & 0.02 & 0.16 & 0.08 & 5.28 & 2.40 & 0.01 & 5 \\
\hline \multirow{2}{*}{$\begin{array}{l}\text { E4, E5- Rio } \\
\text { Branco }\end{array}$} & $0.0-0.2$ & 5.5 & 0.004 & 0.15 & 2.10 & 0.55 & 1.88 & 0.00 & 0.01 & 60 \\
\hline & $0.2-0.4$ & 5.6 & 0.003 & 0.12 & 2.02 & 0.53 & 1.60 & 0.00 & 0.01 & 62 \\
\hline \multirow{2}{*}{$\begin{array}{c}\text { E6 - Alta Floresta } \\
\text { do Oeste }\end{array}$} & $0.0-0.2$ & 6.0 & 0.024 & 0.64 & 8.25 & 0.97 & 5.45 & 0.00 & 0.03 & 64 \\
\hline & $0.2-0.4$ & 6.4 & 0.005 & 0.85 & 5.64 & 0.87 & 3.47 & 0.00 & 0.02 & 68 \\
\hline
\end{tabular}

$\mathrm{pH}$ in water (1: 2.5); O.M. by wet digestion; $\mathrm{P}$ and $\mathrm{K}$ by the Mehlich I method; exchangeable $\mathrm{Ca}, \mathrm{Mg}$, and $\mathrm{Al}$, OM: organic material using 1 mol KC. 


\subsection{Statistical analysis}

\subsubsection{Individual analyses and environmental index}

The significance of the effect of genotypes on the mean yield over three years (bag ha ${ }^{1}$ ) was tested individually in each environment, considering the estimates of the $\mathrm{F}$ test of analysis of variance, the experimental coefficient of variation and the heritability in each environment. To quantify the contribution of the different environments to genotype performance, the environmental quality index $\left(I_{j}\right)$ was estimated based on Eberhart and Russel (1966), according to the following equation:

$$
I_{j}=\bar{y}_{j}-\bar{y}
$$

where is the environmental quality index; $\bar{y}_{j}$ is the overall average of the genotypes in environment $j$; and $\bar{y}$ is the overall average of the genotypes in all the environments. This index allows classification of the environments that have $I_{j}$ greater than or equal to zero as "favorable", and environments with negative $I_{j}$ as "unfavorable".

\subsection{Clustering of the environments: climate and soil characteristics}

To quantify the similarity among the environments, reducing the dimensions of the data, eigenvectors were estimated from the climate characteristics: mean temp $\left({ }^{\circ} \mathrm{C}\right)$, minimum temp $\left({ }^{\circ} \mathrm{C}\right)$, maximum temp $\left({ }^{\circ} \mathrm{C}\right)$, and rainfall $\left.(\mathrm{mm})\right]$ separately from the soil characteristics: $\mathrm{pH}$, phosphorus $\left(\mathrm{g} / \mathrm{dm}^{3}\right)$, potassium $\left(\mathrm{cmolc} / \mathrm{dm}^{3}\right)$, calcium $\left(\mathrm{cmolc} / \mathrm{dm}^{3}\right)$, magnesium $\left(\mathrm{cmolc} / \mathrm{dm}^{3}\right), \mathrm{Al}+\mathrm{H}$ ratio $\left(\mathrm{cmolc} / \mathrm{dm}^{3}\right)$, organic matter $(\mathrm{kg} / \mathrm{kg})$, and base saturation (\%)] (Hair et al., 2009). The two-dimensional scatterplot was thus obtained, whose axes represented the variations of the climate characteristics and of the soil characteristics in each one of them.

\subsection{Combined analysis and effect of the genotype $x$ environment interaction}

After performing the individual analyses of variance and verifying the homogeneity of variances, a combined analysis was performed to quantify the effect of the $\mathrm{G} \times \mathrm{E}$ interaction, according to the model described by Cruz et al. (2014):

$Y_{i j k}=m+G_{i}+B / A_{j k}+A_{j}+G A_{i j}+E_{i j k}$

where $Y_{i j k}$ refers to observation of the $i^{\text {th }}$ genotype in the $k^{\text {th }}$ block and in the $j^{\text {th }}$ environment; $m$ is the experimental average; $G_{i}$ is the effect of the $i^{\text {th }}$ genotype (clone effect); $B / A_{j k}$ is the effect of the $k^{\text {th }}$ block within the $j^{\text {th }}$ environment; $A_{j}$ is the effect of the $j^{\text {th }}$ environment; $G A_{i j}$ is the effect of the interaction between the $i^{\text {th }}$ genotype and the $j^{\text {th }}$ environment; and $E_{i j k}$ is the experimental error. The genotypes were considered to have fixed effects, while the blocks and environmental effect were considered to be random.

\subsection{Clustering of the genotypes and environments}

The Additive Main effects and Multiplicative Interaction (AMMI) analysis according to Gauch et al. (2008) combines additive components for the main effects of genotype $\left(g_{i}\right)$ and environments $\left(a_{j}\right)$, and multiplicative components for the effect of the $\mathrm{G} \times \mathrm{E}$ interaction (geij) in a single model. The model that describes the mean yield of a genotype $i$ in environment $j$ is as follows:

$Y_{i j}=\mu+g_{i}+a_{j}+\sum_{c=1}^{q} \sqrt{\lambda_{k}} \alpha_{j k} \gamma_{i k}+\delta_{i j}+e_{i j}$

where $Y_{i j}$ is the observation of genotype $i$ in environment $j$; $\mu$ is the overall mean; $g_{i}$ is the effect of genotype $i$; $a_{j}$ is the effect of environment $j ; \lambda_{k}$ is the $k^{\text {th }}$ singular value of the original matrix interactions $(\mathrm{G} \times \mathrm{E}) ; \gamma_{i k}$ is the element corresponding to the $i^{\text {th }}$ genotype in the $k^{\text {th }}$ singular vector of the $\mathrm{G} \times \mathrm{E}$ matrix column; $\alpha_{j k}$ is the element corresponding to the $j^{\text {th }}$ environment in the $k^{\text {th }}$ singular vector of the $\mathrm{G} \times \mathrm{E}$ matrix row; $\delta_{i j}$ is the residue not explained by the principal components; and $e_{i j}$ is the average experimental error associated with observation, assumed to be independent and normally distributed $\left[\varepsilon \sim \mathrm{N}\left(0, \sigma^{2}\right)\right]$. Statistical analyses were performed using the Genes software (Cruz, 2016).

Estimates of Pearson correlation were also interpreted to compare the performance of the genotypes in relation to the mean performance of each environment (Resende, 2007; Cruz, 2016).

\subsection{Complex part of the genotype $\times$ environment interaction}

The complex part of the genotype $\times$ environment interaction was estimated between pairs of environments using the equation proposed by Cruz and Castoldi (1991):

$C=\sqrt{(1-r)^{3} \cdot Q_{1} \cdot Q_{2}}$

where $C$ is the complex part of the genotype $\times$ environment interaction; $r$ is the correlation coefficient of the means in environments 1 and 2; $Q_{1}$ is the mean square of genotypes in environment 1 ; and $Q_{2}$ is the mean square of genotypes in environment 2 . The estimates clustered in a symmetric matrix, squared, and with the diagonals equal to zero were used to obtain a tree diagram using UPGMA, so as to cluster the environments according to the complex fraction of the $\mathrm{G} \times \mathrm{E}$ interaction. Statistical analyses were performed using the GENES software (Cruz, 2016). 


\section{RESULTS}

The individual analyses were interpreted to evaluate experimental accuracy and the effect of clones in each environment (Table 3). The estimates of the environmental quality index indicated that the environments of Alta Floresta do Oeste, RO; Rio Branco, RO, irrigated and in dryland; and Ouro Preto do Oeste, RO, were favorable for coffee growing, with mean yields of 77.5, 54.5, 54.4, and 50.6 bags per hectare, respectively (Table 3 ). The favorable environment of Alta Floresta has higher altitude, lower soil acidity, and higher base saturation of an Eutrophic Red Argisol.

The environments of Porto Velho, RO, and Ariquemes, $\mathrm{RO}$, were classified as unfavorable for coffee production (Table 3). The clonal trial of the environment of Ariquemes, $\mathrm{RO}$, conducted on dryland, resulted in the lowest mean yield over three years (21.16 bag ha-1).

The estimates of the $\mathrm{F}$ test of the effect of clones in each environment were significant at $1 \%$ probability, indicating the importance of this effect for coffee yield (Table 3). The high estimates of heritability (amplitude from 0.85 to 0.94 ) also indicated the notable contribution of the effect of clones to expression of this characteristic.

The estimates of the coefficient of variation exhibited an amplitude from $11.11 \%$, observed in the environment of Rio Branco, AC, to $26.54 \%$ in the environment of Ariquemes, RO. The ratio of 2.43 between the lowest and highest estimate of residual variance obtained among these environments indicated that there was homogeneity of variances, thus meeting one of the presuppositions for combined analysis (Cruz et al., 2014).
Combined analysis of variance indicated that the effects of genotypes $(\mathrm{G})$, of environments $(\mathrm{E})$, and of the $\mathrm{G} \times \mathrm{E}$ interaction were significant according to the $\mathrm{F}$ test $(p<.01)$ (Table 3$)$. The significance of the $\mathrm{G} \times \mathrm{E}$ interaction showed that the clones exhibited different performances in the environments evaluated. The overall mean of all the trials was $50.8 \mathrm{bag} \mathrm{ha}^{-1}$, with amplitude from $21.3 \mathrm{bag} \mathrm{ha}^{-1}$ in the municipality of Ariquemes, $\mathrm{RO}$, to $77.5 \mathrm{bag} \mathrm{ha}^{-1}$ in the municipality of Alta Floresta do Oeste, RO. The estimate of the experimental coefficient of variation $\left(\mathrm{CV}_{\mathrm{e}}=17.36\right)$ is associated with good experimental accuracy. The broad-sense heritability estimate $\left(\mathrm{h}^{2}=0.94\right)$ and of the ratio between the genetic and experimental coefficients of variation $(\mathrm{CVg} / \mathrm{CVe}=1.74)$ indicate the importance of the genotypic component for expression of this characteristic, associated with the condition favorable to obtaining gain from selection.

The reduction in dimensionality obtained from eigenvectors estimated using climate and soil characteristics indicated that the environments of Porto Velho, RO; Rio Branco, AC; and Ariquemes, RO, have greater similarity to each other than the environments of Ouro Preto do Oeste, $\mathrm{RO}$, and Alta Floresta, RO, which are differentiated by greater natural fertility of the soil and higher altitude (Figure 1).

The AMMI1 biplot shows that genotypes 16, 10, and 13 exhibited the highest mean yields and low values on the IPCA1 axis, and genotype 13 had the lowest values on this axis (Figure 2).

The predictability of the response of these genotypes can also be verified by the estimates of correlation between their performance and the mean performance of the trials conducted in the different environments $\left(r_{16 . \bar{x}}=0.92, r_{13 . \bar{x}}=0.91, r_{10 . \bar{x}}=0.96\right)$. Genotypes 14, 1, 20, 15, and 12 had yield higher than the mean of the experiments, along with high stability. Genotypes 4, 19, and 9 had high yield, along with lower stability.

Table 3: Summary of the individual and combined analyses of six clonal competition trials evaluated in five environments of the Western Amazon.

\begin{tabular}{|c|c|c|c|c|c|}
\hline \multicolumn{6}{|c|}{ Individual analysis } \\
\hline Environment & $\begin{array}{c}\text { Yield } \\
\left(\text { bag ha }^{-1}\right)\end{array}$ & $\mathrm{I}_{\mathrm{j}}$ & $\mathrm{CVe}$ & $\mathrm{F}^{\#}$ & $\mathrm{~h}^{2}$ \\
\hline E1 - Ouro Preto do Oeste ${ }^{1}$ & 50.6 & 3.96 & 24.57 & $6.67 * *$ & 0.85 \\
\hline E2 - Porto Velho ${ }^{1}$ & 44.8 & -6.78 & 19.88 & $17.20^{* *}$ & 0.94 \\
\hline E3 - Ariquemes ${ }^{2}$ & 21.3 & -30.43 & 26.54 & $9.40 * *$ & 0.89 \\
\hline E4 - Rio Branco ${ }^{1}$ & 54.5 & 3.9 & 11.8 & $21.09 * *$ & 0.93 \\
\hline E5 - Rio Branco ${ }^{2}$ & 54.4 & 3.46 & 11.11 & $21.67 * *$ & 0.94 \\
\hline E6 - Alta Floresta do Oeste ${ }^{1}$ & 77.5 & 25.91 & 14.18 & $12.23 * *$ & 0.92 \\
\hline \multicolumn{6}{|c|}{ Combined analysis } \\
\hline All environments & $\begin{array}{c}\text { Yield } \\
\left(\text { bag ha }^{-1}\right)\end{array}$ & $\mathrm{CVg}$ & $\mathrm{CVe}$ & $\mathrm{F}^{\$}$ & $\mathrm{~h}^{2}$ \\
\hline E1, E2, E3, E4, E5, E6 & 50.8 & 30.34 & 17.36 & $3.45^{* *}$ & 0.94 \\
\hline
\end{tabular}

Yield: mean yield over three years, lj: environmental quality index, CVe: experimental coefficient of variation, $\mathrm{F}^{\#:} \mathrm{F}$ test of analysis of variance that tests the effect of clones (genotypes), $\mathrm{h}^{2}$ : mean heritability in each environment. $\mathrm{CVg}$ : genetic coefficient of variation, $\mathrm{F}^{\$}$ : $\mathrm{F}$ test of analysis of variance that tests the effect of the genotype $\times$ environment interaction, $\mathrm{h}^{2}$ : broad-sense heritability. ${ }^{1}$ Trial conducted using irrigation, ${ }^{2}$ Trial conducted under dryland conditions. 


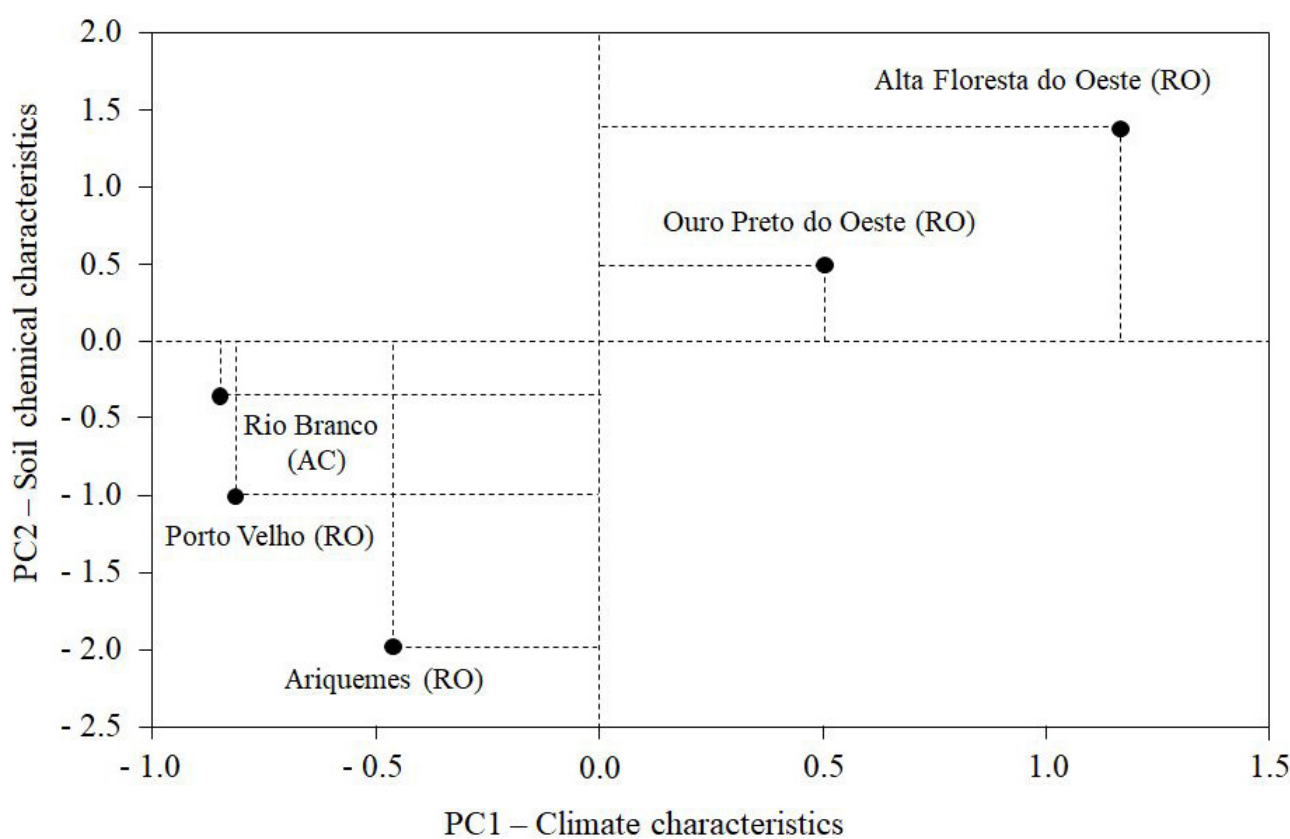

Figure 1: Scattering on the plane between the first principal component estimated from soil variables (64\%) and of the first principal component estimated from climate variables (81\%) of five environments of the Western Amazon.

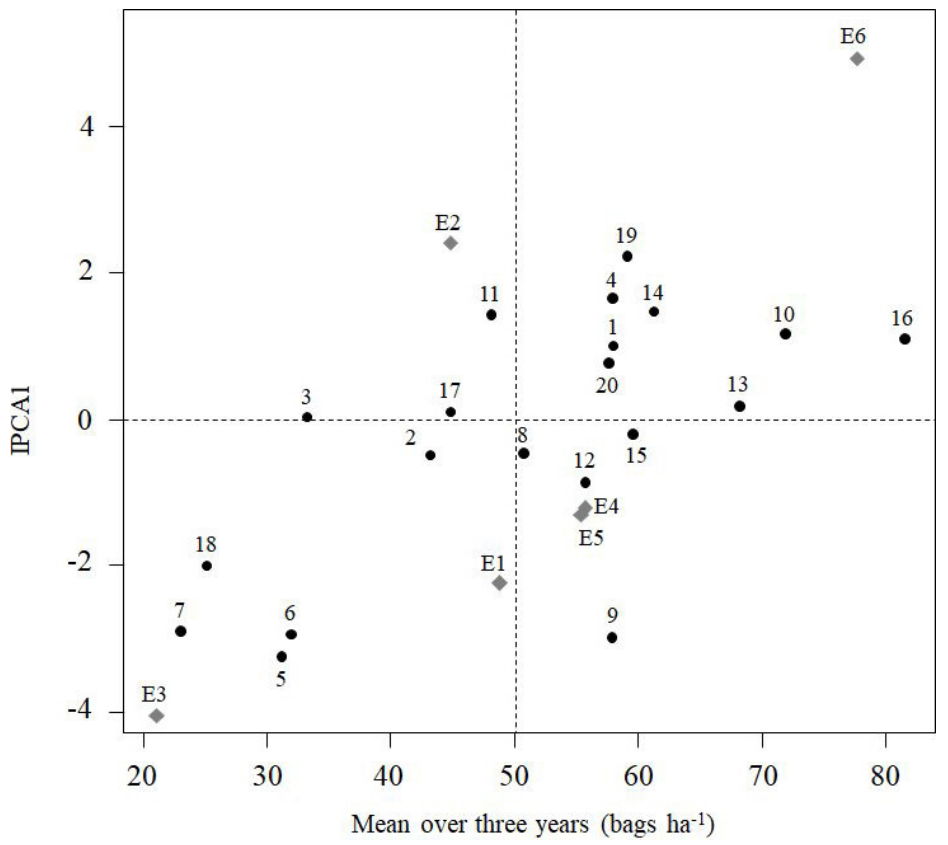

Figure 2: Scattering on the plane estimated using the AMMI method for evaluation of yield performance of 20 genotypes in six clonal competition trials (E1 to E6) grown in five environments of the Western Amazon. The genotypes and the environments with their respective reference numbers are identified in Table 1.

Genotypes 2, 3, and 17, in turn, had stability in their response, along with lower yield. And genotypes 18, 7, 6, 5, and 11 had low yield and low stability. The favorable environment of Alta Floresta do Oeste, RO (E6) was nearer genotypes 16, 13 , and 10 and farther from the other environments. Genotypes of greater proximity to determined environments have higher specific stability for those locations (Gauch et al., 2008).
In the AMMI2 scatterplot (IPCA1 $\times$ IPCA2), the mega-environment is defined by the clustering of two or more environments in a single sector, delimited by the lines that originate from the center of the scatterplot (Figure 3). In this biplot, only the E4 and E5 environments were clustered in the same sector. Genotypes 16, 10, 13, and 15 showed specific adaptation to the best environment, Alta Floresta do Oeste (E6). 
The tree diagram estimated from the matrix of the complex fraction of the $\mathrm{G} \times \mathrm{E}$ interaction between pairs of environments was also used to cluster the environments that have similar biotic and abiotic stress conditions, complementing definition of mega-environments (Figure 4). The cut-off point established at the position of greatest divergence among the environments coincides with the clustering of the AMMI scatterplot that clustered the E4 and E5 environments of the Rio Branco municipality in the same mega-environment. Hierarchical clustering showed that the E3, E2, E6, and E1 environments represent the environments most divergent from the cluster formed by E4 and E5.

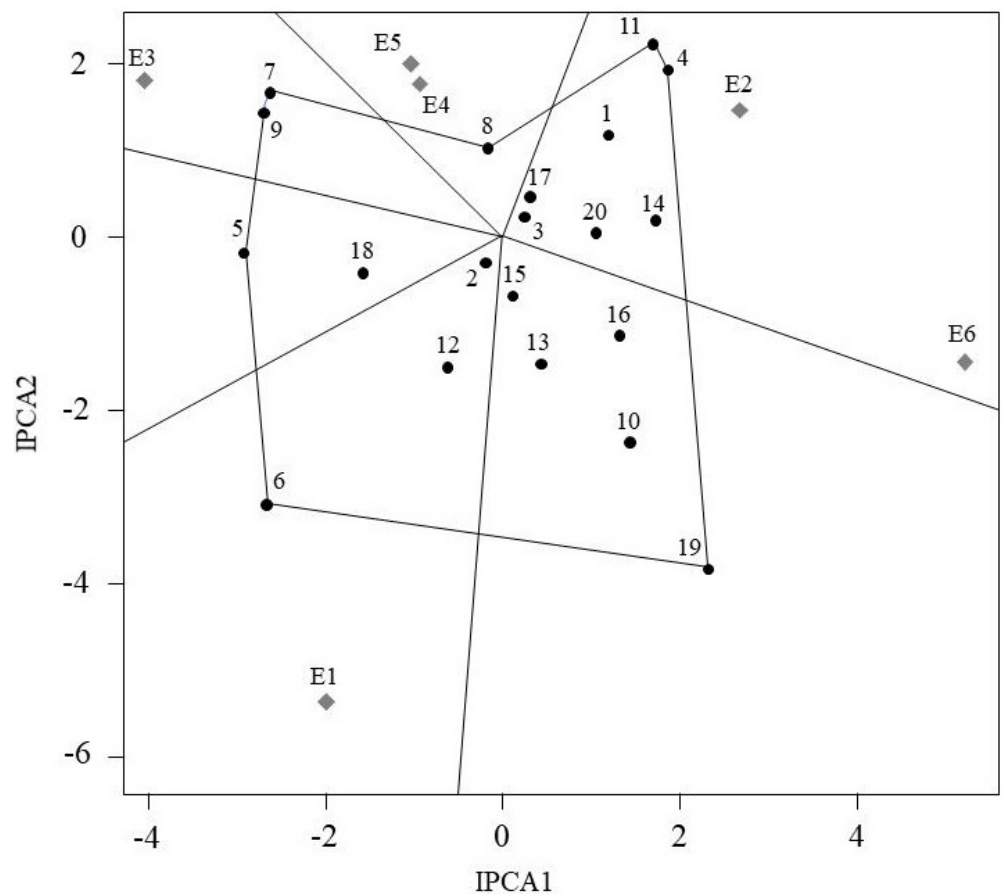

Figure 3: Scatterplot obtained from the first and second principal components estimated using the AMMI method for evaluation of yield performance of 20 genotypes in six clonal competition trials (E1 to E6) grown in five environments of the Western Amazon. Environments located in the same sector delimited by continuous lines are clustered in the same group.

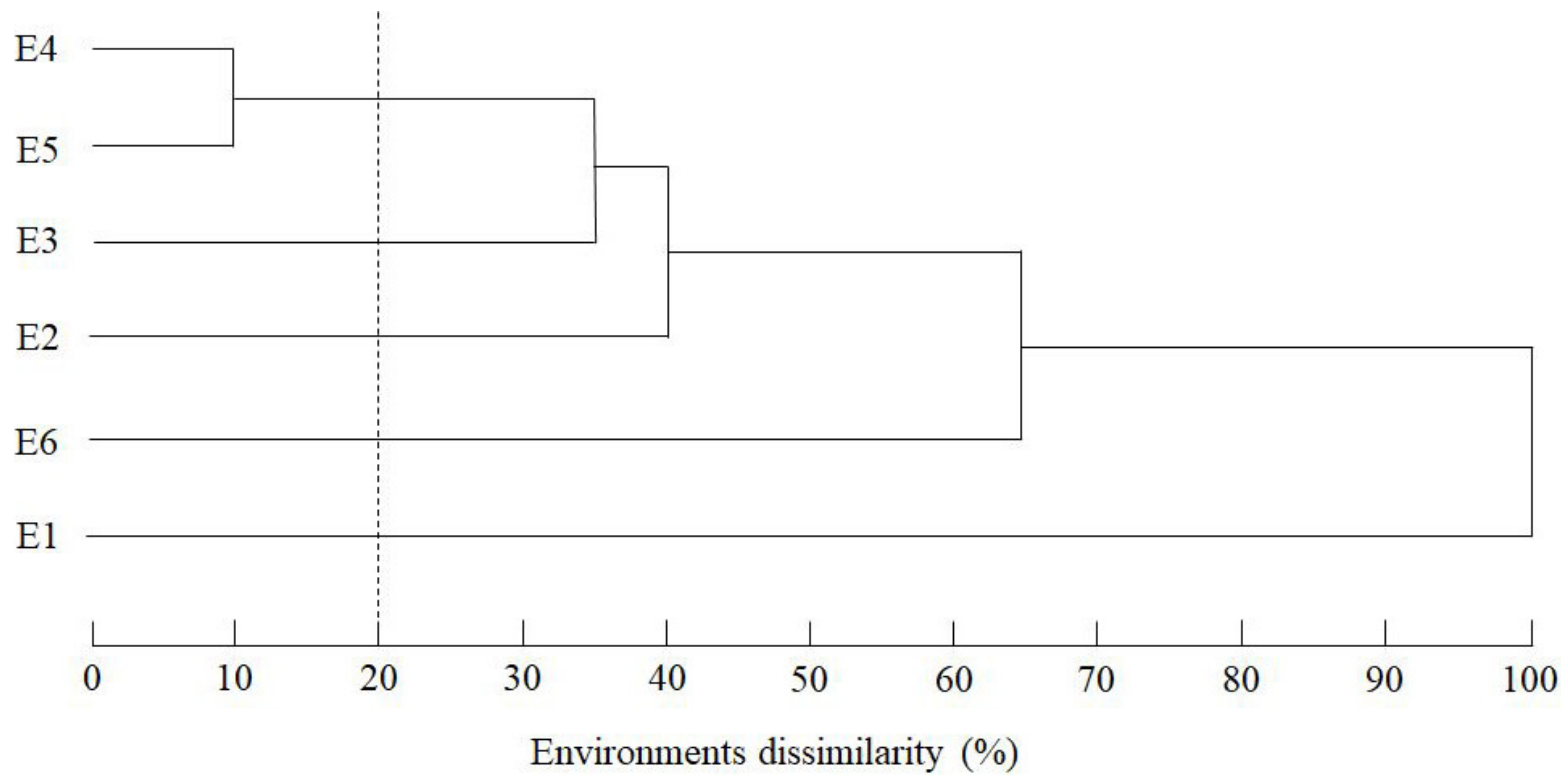

Figure 4: Dendrogram representing the dissimilarity of the environments estimated using the UPGMA algorithm from the matrix containing the complex part of the G×E interaction. The cut-off point was established in the clustering of greatest divergence among the environments. 


\section{DISCUSSION}

This study details the response of clones grown in the Western Amazon considering the performance of the plants in contrasting environments, such as the trial without irrigation, set up in the municipality of Ariquemes, RO, and the trial under higher altitude and greater natural fertility conditions, set up in Alta Floresta do Oeste, RO. Moraes et al. (2020) evaluated the performance of the genotypes prior to their registration in the Brazilian Ministry of Agriculture (MAPA/RNC, 2020) in a smaller number of environments and also classified the environments of Ariquemes and Porto Velho as unfavorable for coffee production.

The environments of Ariquemes, RO, and Porto Velho, RO, classified as unfavorable for coffee production are identified by agricultural zoning of the state of Rondônia as less suitable for coffee growing in their Dystrophic Yellow Oxisols. In addition to lower soil fertility, the crop in Ariquemes was established without irrigation, aiming to evaluate the response of the clones under dryland conditions. Correlation between the performance of the genotypes in this environment and the other locations showed amplitude from 0.60 to $0.87\left(\mathrm{r}_{\mathrm{E} 1 \mathrm{E} 3}=0.60, \mathrm{r}_{\mathrm{E} 2 \mathrm{E} 3}=0.80, \mathrm{r}_{\mathrm{E} 3 \mathrm{E} 4}=0.87, \mathrm{r}_{\mathrm{E} 3 \mathrm{E} 5}=0.79\right.$, $\left.r_{\mathrm{E} 3 \mathrm{E} 6}=0.70\right)$. Genotypes 16,10 , and 13 were highest yielding in this environment, followed by genotypes 9 and 12, which did not have high yields in other environments.

Environments E6, E1, E4, and E5 were considered favorable for coffee growing, especially the E6 environment, which had a mean that was $52 \%$ higher than the overall mean of all the trials. The favorable environment of Alta Floresta differs from the others by higher altitude, lower soil acidity, and higher base saturation. Correlation between the ranking of the genotypes in this environment with the other locations showed an amplitude from 0.70 to $0.83\left(\mathrm{r}_{\mathrm{E} 1 \mathrm{E} 6}=0.70, \mathrm{r}_{\mathrm{E} 2 \mathrm{E} 6}=\right.$ $\left.0.83, \mathrm{r}_{\mathrm{E} 3 \mathrm{E} 6}=0.70, \mathrm{r}_{\mathrm{E} 4 \mathrm{E} 6}=0.79, \mathrm{r}_{\mathrm{E} 5 \mathrm{E} 6}=0.78\right)$. Genotypes 10 and 16 were the highest yielding in this environment, followed by clones $19,14,1$, and 13 . Of this set, clone 19 was characterized by exhibiting greater yield only in this environment.

Even considering the higher estimates of the coefficient of variation observed in the non-irrigated environment of Ariquemes, the experimental accuracy had a magnitude similar to that observed in other studies (Montagnon et al., 2003; Martins et al., 2019). Combined analysis, in turn, indicated the genotype $\times$ environment $(\mathrm{G} \times \mathrm{E})$ interaction as significant. The significant $\mathrm{G} \times \mathrm{E}$ interaction hinders identification of genotypes of wide adaptation since this interaction is characterized by the change in performance of the clones in the different environments (Ferrão et al., 2008; Montagnon et al., 2008; Damatta et al., 2018), however, it allows for selection of location specific genotypes.

Change in yield performance in different environments is a characteristic of the coffee plant that has been observed in other studies. Significant $\mathrm{G} \times \mathrm{E}$ interactions were also observed in evaluation of several clones in different environments in Ivory Coast (Montagnon et al., 2008) and in evaluation of clones of the Conilon botanical variety grown in the state of Espírito Santo in Brazil (Ferrão et al., 2008). Similarly, Moraes et al. (2020) observed significant $G \times E$ interaction in the region investigated in this study in environments classified as unfavorable for coffee growing.

Success in selection of plants of greater adaptability and stability is associated with the magnitude of the genotypic effects (Rocha et al., 2021; Bikila et al., 2017). Heritability estimates ranging from 0.80 to 0.90 realized in this study were also observed by Resende et al. (2001) in evaluation of Coffea arabica cultivars in the Southeast region of Brazil. Ferrão et al. (2008), Ramalho et al. (2016), and Silva et al. (2018) also observed heritability estimates for yield higher than 0.80 in evaluation of $C$. canephora genotypes in the states of Espírito Santo and Rondônia in Brazil. In field trials evaluated in Ghana, Akpertey, Anim-Kwapong and Ofori (2018) observed that heritability estimates are higher at early years of production. In similar trials, significant associations between yield and some juvenile vegetative growth traits were observed (Akpertey; Anim-Kwapong; Ofori, 2019).

Change in the performance of the clones from one environment to another can be of the simple type, when there is no change in the ranking of the clones from one environment to another, or of the complex type, when the best genotypes in one environment are not the best in other environments (Silva et al., 2019; Partelli et al., 2020). The greater stability of genotype 13 in comparison to genotypes 16 and 10 is due to the lower performance of genotype 10 in the environment of Porto Velho $\left(\bar{x}_{16}=88.67, \bar{x}_{13}=72.27\right.$, and $\left.\bar{x}_{10}=60.97\right)$ and greater response to improvement of the environment of the genotypes 16 and 10 grown in Alta Floresta do Oeste $\left(\bar{x}_{16}=106.47, \bar{x}_{13}=91.00\right.$, and $\left.\bar{x}_{10}=111.40\right)$. Genotypes $14,1,20,15$, and 12 had yield superior to the mean of the experiments, along with high stability. Genotypes 14 and 20 not only have yields higher than the mean, but are differentiated by higher beverage quality and hardiness, respectively (Teixeira et al., 2020).

The trials were set up with clones of the cultivar Conilon BRS Ouro Preto, registered in the year 2013 (genotypes 1, 2, and 3); clones from the cultivar Robustas Amazônicos, registered in the year 2019 (genotypes 16, 13, 10 14, 4, 8, and 20); and other clones selected under experimental conditions $(5,6,7,9,11,12,15,16,17,18$, and 19). In general, were observed superiority of the full-sib clones derived from the directed pollination between Conilon and the Robusta botanical varieties, which exhibited greater overall adaptability. Heterosis, also called hybrid vigor, characterized by the greater vigor observed in the individual hybrids, is observed in this allogamous and self-incompatible species 
(Leroy et al., 1997; Davis et al., 2006; Montagnon et al., 2008; Oliveira et al., 2018). Hybrids of smaller size with the drought resistance of Conilon, together with the greater sieve and resistance to the pests and diseases of Robusta have stood out in field evaluations (Souza et al., 2013; Dalcomo et al., 2015; Ramalho et al., 2016).

We found greater specific adaptability of the coffee clones in our current study comparable with the findings of Bergo et al. (2020) who observed greater specific adaptability of coffee plants selected in the Amazon region compared to coffee plants selected in other regions. This higher vigor and yield may be due to the adaptability of those plants to the edaphic and climatic conditions of the Western Amazon, which is characterized by soil acidity, high rainfall, and a welldefined dry season.

Another interesting characteristic was conducting two trials in the same environment so as to consider the variation among environments and within the same environment. Environments E4 and E5 clustered near each other in the two scatterplots, having been allocated to the same group. Both the AMMI2 biplot (Figure 3) and the hierarchical cluster estimated from the complex part of the genotype $\times$ environment interaction (Figure 4) indicated that only environments E4 and E5 grown in the municipality of Rio Branco, AC, were clustered in the same mega-environment. The dendrogram showed that the environments are most similar one to another in the following order: E4, E5, E3, E2, E6, E1.

The term mega-environment refers to locations that are not necessarily near but that have similar conditions and similar biotic and abiotic stresses. This definition aims at rationalizing evaluation through allocation of resources in different locations to better predict the response of the genotypes, increasing the efficiency of breeding programs (Gauch et al., 2008). Except for environments E4 and E5, all the environments proved to be locations with different biotic and abiotic stress conditions. This result shows the importance of maintaining evaluations in these locations, which may represent conditions of coffee fields in this region.

\section{CONCLUSIONS}

The reduction in the dimensionality of the data, estimated from climate and soil characteristics, indicated that the environments of Porto Velho, RO; Rio Branco, $\mathrm{AC}$; and Ariquemes, RO, have greater similarity than the environments of Ouro Preto do Oeste, RO, and Alta Floresta, $\mathrm{RO}$, which are differentiated by greater natural fertility of the soil and higher altitude.

The AMMI1 biplot, which associates clone performance with their stability, showed that genotypes 16 (BRS1216), 10 (BRS 3210), and 13 (BRS 3213) had the highest mean yields, together with higher stability.
In the AMMI2 biplot (IPCA $1 \times$ IPCA2), the environments E4 and E5 were clustered in the same sector, delimited by the lines originating from the center of the scatterplot.

Clustering based on the complex fraction of the $\mathrm{G} \times \mathrm{E}$ interaction coincided with the AMMI2 scatterplot that clustered the E4 and E5 environments in a single megaenvironment. Except for these environments, all the others clustered as locations of different biotic and abiotic stress conditions. This result shows the importance of maintaining evaluations in these environments and should guide future breeding, selection efforts as well as C. canephora production in the Western Amazon region.

\section{ACKNOWLEDGMENTS}

The authors are grateful to CAPES (Coordenação de Aperfeiçoamento de Pessoal de Nível Superior - Brasil Finance Code 001) for scholarships. They are also grateful to CPC (Consórcio Brasileiro de Pesquisa e Desenvolvimento do Café) and to $\mathrm{CNPq}$ (Conselho Nacional de Desenvolvimento Científico e Tecnológico) for financial support.

\section{REFERENCES}

AKPERTEY, A.; ANIM-KWAPONG, E.; OFORI, A. Genetic Variation among Robusta coffee genotypes for growth and yield traits in Ghana. Journal of Agricultural Science, 10(4):138-149, 2018.

AKPERTEY, A.; ANIM-KWAPONG, E.; OFORI, A. Early selection for yield in robusta coffee based on juvenile growth traits. African Crop Science Journal, 27(4):571584, 2019.

ALVARES, C. A. et al. Koppen's climate classification map for Brazil. Meteorologische Zeitschrift, 22(6):711-728, 2013.

BERGO, L. et al. Estimation of genetic parameters and selection of Coffea canephora progenies evaluated in Brazilian Western Amazon. Coffee Science, 15(1):e151663, 2020.

BIKILA, B. A.; SAKIYAMA, N. S. Estimation of genetic parameters in Coffea canephora Var. Robusta. Advances in Crop Science and Technology, 5(5):310, 2017.

CARIAS, C. M. O. M. et al. Predição de ganhos genéticos via modelos mistos em progênies de café conilon. Coffee Science, 11(1):39-45, 2016.

COMPANHIA NACIONAL DE ABASTECIMENTO - CONAB. Acompanhamento de safra brasileiro grãos: safra 2019/2020: Brasília: Companhia Nacional de Abastecimento. 2020. Available in: <http://www.conab. gov.br/OlalaCMS>. Access in: Mach, 02, 2021. 
CILAS, C. et al. Yield stability in clones of Coffea canephora in the short and medium term: longitudinal data analyses and measures of stability over time. Tree Genetics \& Genomes, 7:421-429, 2011.

CRUZ, C. D. et al. Modelos biométricos aplicados ao melhoramento genético. Viçosa, Minas Gerais: Universidade Federal de Viçosa, 2014. 668p.

CRUZ, C. D.; CASTOLDI, F. Decomposição da interação genótipo $\mathrm{x}$ ambientes em partes simples e complexa. Revista Ceres, 38(1):422-430, 1991.

CRUZ, C. D. Genes Software - Extended and integrated with the R, matlab and selegen. Acta Scientiarum Agronomy, 38(4):547-552, 2016.

DALAZEN, J. R. et al. Base genética da cafeicultura e caracterização dos principais clones cultivados no estado de Rondônia. In: PARTELLI, F. L.; ESPINDULA, M. C. Café conilon: Conhecimento para superar desafios. Alegre: CAUFES, v. 1, p. 165-177, 2019.

DALCOMO, J. et al. Evaluation of genetic divergence among clones of conilon coffee after scheduled cycle pruning. Genetics and Molecular Research, 14(4):15417-15426, 2015.

DAMATTA F. M. et al. Physiological and agronomic performance of the coffee crop in the context of climate change and global warming: A review. Journal of Agricultural and Food Chemistry, 66:5264-5274, 2018.

DAVIS, A. et al. An annotated taxonomic conspectus of the genus Coffea (Rubiaceae). Botanical Journal of the Linnean Society, 152(4):465-512, 2006.

FERRÃO, R. G. et al. Genetic parameters in Conilon coffee. Pesquisa Agropecuária Brasileira, 43(1):61-69, 2008.

EBERHART, S. A. T.; RUSSELL, W. A. Stability parameters for comparing varieties 1. Crop Science, 6(1):36-40, 1966.

FERRÃO, R. G. et al. Melhoramento genético de Coffea canephora. In: FERRÃO, R. G. et al. Café conilon. Vitoria: DCM/Incaper, v. 1, p. 131-175, 2017.

GAUCH, H. G., et al. Statistical analysis of yield trials by AMMI and GGE: Further considerations. Crop Science, 48(3):866-889, 2008

HAIR, J. R. et al. Multivariate data analysis. Upper Saddle River, Nova Jersey: Prentice Hall, 2009, 761p.

LEROY, T. et al. Reciprocal recurrent selection applied to Coffea canephora Pierre. III. Genetic gains and results of first cycle intergroup crosses. Euphytica, 95(3):347-354, 1997.
MAPA/RNC. Registro Nacional de cultivares RNC. 2020. Available at: http://www.agricultura.gov.br/guia-deservicos/registro-nacional-de-cultivares-rnc. Access in: February,08,2021.

MARCOLAN, A. L. et al. Cultivo dos cafeeiros Conilon e Robusta para Rondônia. Porto Velho, Rondônia: Embrapa Rondônia, 2009. 61p.

MARTINS, M. Q. et al. Adaptability and stability of Coffea canephora genotypes cultivated at high altitude and subjected to low temperature during the winter. Scientia Horticulturae, 252:238-242, 2019.

MISTRO, J. C. et al. Effective population size and genetic gain expected in a population of Coffea canephora. Crop Breeding and Applied Biotechnology, 19(1):1-7, 2019.

MONTAGNON, C. et al. Heritability of Coffea canephora yield estimated from several mating designs. Euphytica, 133(2):209-218, 2003.

MONTAGNON, C. et al. Heterozygous genotypes are efficient testers for assessing between-population combining ability in the reciprocal recurrent selection of Coffea canephora. Euphytica, 160:101-110, 2008.

MORAES, M. S. et al. Adaptability and stability of Coffea canephora pierre ex froehner genotypes in the Western Amazon. Ciência Rural, 50(1):e20190087, 2020.

OLIVEIRA L. N. L. et al. Selection of Coffea canephora parents from the botanical varieties Conilon and Robusta for the production of intervarietal hybrids. Ciência Rural, 48:e20170444, 2018.

PARTELLI, F. L. et al. Tributun: A coffee cultivar developed in partnership with farmers. Crop Breeding and Applied Biotechnology, 20:e30002025, 2020.

RAMALHO, A. R. et al. Genetic gain in the productivity of processed coffee from the selection of clones of 'Conilon' coffee. Revista Ciência Agronômica, 47(3):516-523, 2016.

RESENDE, M. D. V. et al. Precision and quality control in variety trial. Pesquisa Agropecuária Tropical, 37(3):182-194. 2007.

RESENDE, M. D. V. et al. Estimativas de parâmetros genéticos e predição de valores genotípicos no melhoramento do cafeeiro pelo procedimento REML/ BLUP. Bragantia, 60(3):185-193, 2001.

ROCHA, R. B. et al. Adaptabilidade e estabilidade da produção de café beneficiado em Coffea canephora. Ciência Rural, 45(9):1531-1537, 2015. 
ROCHA, R. B. et al. Coffea canephora breeding: Estimated and achieved gains from selection in the Western Amazon, Brazil. Ciência Rural, 51(5):e20200713, 2021.

SILVA, D. O. et al. Genetic progress with selection of Coffea canephora clones of superior processed coffee yield. Ciência Rural, 48(3):e20170443, 2018.

SILVA, V. A. et al. Selection of conilon coffee clones tolerant to pests and diseases in Minas Gerais. Crop Breeding and Applied Biotechnology, 19(3):269276, 2019.

SOUZA, F. F. et al. Molecular diversity in Coffea canephora germplasm conserved and cultivated in
Brazil. Crop breeding and applied biotechnology, 13(4):221-227, 2013.

SPINELLI, V. M. et al. Contribution of agronomic traits to the yield of Coffea canephora hulled coffee. Coffee Science, 13(3):333-340, 2018.

SCHLINDWEIN, J. A. et al. Solos de Rondônia: Usos e perspectivas. Revista Brasileira de Ciências da Amazônia, 1(1):213-231, 2012.

TEIXEIRA, A. L. et al. Amazonian Robustas - new Coffea canephora coffee cultivars for the Western Brazilian Amazon. Crop Breeding and Applied Biotechnology, 20:e323420318, 2020 . 